\title{
Lineage conversion of mouse fibroblasts to pancreatic $\boldsymbol{\alpha}$-cells
}

\author{
Tianjin Liu ${ }^{1,8}$, Liangliang Sun ${ }^{2,8}$, Beige Jiang ${ }^{3,8}$, Limei $\mathrm{Li}^{4,5,8}$, Jin Cen ${ }^{1}$, Xiaotao Chen ${ }^{1}$, Zhaoyun Zhang, \\ Qinghua Wang ${ }^{7}$, Xin Cheng 1 , Yongquan $\mathrm{Shi}^{2}$ and Lijian Hui ${ }^{1}$
}

$\alpha$-cells, which synthesize glucagon, also support $\beta$-cell survival and have the capacity to transdifferentiate into $\beta$-cells. However, the role of $\alpha$-cells in pathological conditions and their putative clinical applications remain elusive due in large part to the lack of mature $\alpha$-cells. Here, we present a new technique to generate functional $\alpha$-like cells. $\alpha$-like cells (iAlpha cells) were generated from mouse fibroblasts by transduction of transcription factors, including Hhex, Foxa3, Gata4, Pdx1 and Pax4, which induce $\alpha$-cell-specific gene expression and glucagon secretion in response to $\mathrm{KCl}$ and Arg stimulation. The cell functions in vivo and in vitro were evaluated. Lineage-specific and functional-related gene expression was tested by realtime PCR, insulin tolerance test (ITT), glucose tolerance test (GTT), Ki67 and glucagon immunohistochemistry analysis were done in iAlpha cells transplanted nude mice. iAlpha cells possess $\alpha$-cell function in vitro and alter blood glucose levels in vivo. Transplantation of iAlpha cells into nude mice resulted in insulin resistance and increased $\beta$-cell proliferation. Taken together, we present a novel strategy to generate functional $\alpha$-like cells for the purposes of disease modeling and regenerative medicine.

Experimental \& Molecular Medicine (2017) 49, e350; doi:10.1038/emm.2017.84; published online 30 June 2017

\section{INTRODUCTION}

Current therapies for the treatment of type I diabetes include daily administration of exogenous insulin and, less frequently, whole-pancreas or islet transplantation. However, insulin injections often result in hypo and/or hyperglycemic episodes as a result in inaccurate dosing, leading to long-term complications. Transplantation of isolated islets or the entire pancreas to recover islet dysfunction has yielded some promising results. ${ }^{1,2}$ However, limited availability of high-quality islet donors has greatly restricted the clinical application of islet transplantation., ${ }^{3,4}$ Therefore, identifying alternative sources of islets or the $\alpha$ - and $\beta$-cells within islets has attracted great attentions. ${ }^{5}$

Within islets, energy homeostasis is maintained by $\beta$-cells that secrete insulin and $\alpha$-cells that secrete glucagon in response to a variety of nutrient, neural and hormonal factors, ${ }^{6}$ regulating blood glucose balance. Following an overnight fast, plasma glucagon levels rise once glucose falls below a threshold ${ }^{7}$ and decreases progressively until plasma glucose rises above the normal range. ${ }^{8} \alpha$-cell dysfunction may have a role in type II diabetes, which may lead to abnormal glucagon secretion and finally hypoglycemia and hyperglycemia in diabetes. ${ }^{9}$ In addition to maintaining plasma glucose levels, $\alpha$-cells may also protect and transdifferentiate into new $\beta$-cells. ${ }^{10-12}$ However, due to the limited accessibility and quantity of $\alpha$-cell populations, the function of these cells within pancreatic islets remains an enigma.

Previous studies have demonstrated pancreatic acinar cell reprogramming into $\alpha$-, $\beta$ - and $\gamma$-cells. ${ }^{13}$ Induced endocrine cell differentiation in vitro has also been previously achieved using embryonic stem cells (ES), induced pluripotent stem cells (iPS), and human pluripotent stem cells (hPSC). ${ }^{14-18}$

\footnotetext{
${ }^{1}$ Institute of Biochemistry and Cell Biology, Institute of Health Sciences, Shanghai Institutes for Biological Sciences (SIBS), Chinese Academy of Sciences (CAS), Shanghai, China; ${ }^{2}$ Department of Endocrinology and Metabolism, Changzheng Hospital, Second Military Medical University, Shanghai, China; ${ }^{3}$ Department of Hepatic Surgery, Eastern Hepatobiliary Surgery Hospital, Second Military Medical University, Shanghai, China; ${ }^{4}$ Research Center for Translational Medicine, Shanghai East Hospital, Tongji University School of Medicine, Shanghai, China; ${ }^{5}$ Department of vascular surgery, Shanghai East Hospital, Tongji University School of Medicine, Shanghai, China; ${ }^{6}$ Department of Endocrinology and Metabolism, Huashan Hospital, Shanghai, China and ${ }^{7}$ Division of Endocrinology and Metabolism, The Keenan Research Centre in the Li Ka Shing Knowledge Institute, St Michael's Hospital, Toronto, Canada ${ }^{8}$ These authors contributed equally to this work.

Correspondence: Dr Y Shi, Department of Endocrinology, Changzheng Hospital, Second Military Medical University, No. 415, Road Fengyang, Shanghai 200003, China.

E-mail: young.stone@163.com

or Dr L Hui, Institute of Biochemistry and Cell Biology, Institute of Health Sciences, Shanghai Institutes for Biological Sciences (SIBS), Chinese Academy of Sciences (CAS), No. 320, Road Yueyang, Shanghai 200031, China.

E-mail: tjliu@sibcb.ac.cn

Received 17 October 2016; revised 23 January 2017; accepted 25 January 2017
} 
However, these cells were dysfunctional and coexpressed mixed pancreatic hormones in vitro. Dynamic chromatin remodeling during ES/iPS differentiation repressed endocrine cell maturation. ${ }^{19}$ In addition, the clinical usage of partially differentiated cells from ES and iPS may present an unacceptable risk of tumor formation. Thus, new protocols to induce endocrine cell redifferentiation are required.

Forced expression of lineage-specific transcription factors directly convert terminally differentiated cells into other celltype lineages. ${ }^{20}$ Recent studies have shown that cardiomyocytes, neurons, and hepatocytes can be induced from mouse fibroblasts by overexpression of defined transcription factors. ${ }^{17,21,22}$ We previously have reported that overexpression of Hnfla, gata4 and Foxa 3 can convert mouse fibroblasts into functional hepatocyte-like cells (iHep cells). ${ }^{17}$ Furthermore, expression of $P d x 1, N g n 3$ and Mafa in vivo reprogrammed pancreatic exocrine cells to $\beta$-like cells. ${ }^{23,24}$ Therefore, we postulated that reprogramming terminally differentiated cells in vitro could generate endocrine cells. The objective of this study was to develop a protocol for the in vitro conversion of mouse fibroblasts into functional, terminally differentiated $\alpha$-cells by Hhex, Foxa3, Gata4, Pdx1 and Pax4 overexpression. The resultant cells acquired $\alpha$-cells function in vitro, such cells were named iAlpha cells. Furthermore, iAlpha cells in the kidney of nude mice induced insulin resistance and promoted $\beta$-cell proliferation. On the basis of this study, iAlpha cells may represent a novel tool for drug discovery, diabetes disease modeling and regenerative medicine.

\section{MATERIALS AND METHODS}

\section{Animal models}

$p 19^{A r f-/-}$ mice and nude mice were maintained in specific pathogenfree husbandry conditions. Nude mice were used as the recipient of iAlpha cells to reduce immunological rejection following their transplantation.

\section{Molecular cloning and lentivirus production}

A multi-cloning site ( $5^{\prime}$-CGGGATCCCGGCGCGCCGACTAGTCGA CGCGTCGAGGTAACCTACGGACCGGTTT-3') was inserted into the PmeI restriction site of the lentiviral vector, pWPI (Addgene, Cambridge, MA, USA). cDNAs of candidate genes were cloned into the modified pWPI plasmid. Plasmids were then introduced to 293FT cells together with the packaging plasmid, psPAX2 (Addgene), and the envelope plasmid, pMD2.G (Addgene). After $48 \mathrm{~h}$, the medium containing lentiviruses was collected and passed through a $0.45-\mathrm{mm}$ filter.

\section{Fibroblast cultures}

To isolate tail-tip fibroblasts (TTF), a $5-\mathrm{cm}$ portion of tail was cut from two-month-old $p 19^{A r f-/-}$ mice. After the dermis was removed, the remaining tissues were minced and incubated with $0.25 \%$ trypsin (Gibco) at $37^{\circ} \mathrm{C}$ for $15 \mathrm{~min}$. Two pieces were placed per $60-\mathrm{mm}$ collagen-I-coated dish in $5 \mathrm{ml}$ of DMEM (Sigma-Aldrich, St Louis, MO, USA) containing 10\% FBS (Sigma-Aldrich). After 5 days, fibroblasts that migrated out of the tissue were transferred to new collagen-I-coated dishes. We used TTFs between passages 7 and 9 for iAlpha cell induction.

\section{iHep cultures}

TTFs were seeded on collagen-I-coated dishes and infected with lentiviruses expressing transcription factors. Cells were then cultured in Block's medium containing $0.1 \mu \mathrm{M}$ dexamethasone, $20 \mu \mathrm{g} \mathrm{ml}^{-1}$ TGF $\alpha, 10 \mu \mathrm{g} \mathrm{ml}^{-1} \mathrm{EGF}, 4.2 \mathrm{mg} \mathrm{ml}^{-1}$ insulin, $3.8 \mathrm{mg} \mathrm{ml}^{-1}$ human transferrin and $5 \mu \mathrm{g} \mathrm{ml}^{-1}$ sodium selenite. Fourteen days after infection, we treated cells with $0.01 \%$ trypsin and discarded detached fibroblastic cells to enrich the epithelial cells. ${ }^{17}$

\section{$\alpha$-cell induction}

Fibroblasts $5 \times 10^{3}$ cells per well were inoculated in 96-well plates one day before virus infection. In each well, $1 \times 10^{8} \mathrm{TU} \mathrm{ml}^{-1}$ of virus was added to obtain a multiplicity of infection (MOI) of 20 for an $80 \%$ infection rate for $72 \mathrm{~h}$.

\section{Cell proliferation analysis}

iAlpha cells were seeded into 96-well plates (1000 cells per well), and the cells were collected at days $0,3,5,7$ and 9. Cell proliferation was measured using a CCK8 kit (Beyotime Biotechnology, China).

\section{Primary islet isolation and culture}

The pancreas was collected from the adult $p 19^{A r f-/-}$ mice and transferred to a $15 \mathrm{ml}$ tube containing $5 \mathrm{ml}$ of cold collagenase $\mathrm{P}$ (Roche, San Francisco, CA, USA). Following incubation for 18-20 min in a $37^{\circ} \mathrm{C}$ water bath, the tissues were washed with $5 \mathrm{ml}$ of quenching buffer consisting of HBSS with 10\% FBS and isolated by centrifugation at $300 \times \mathrm{g}$ for $3 \mathrm{~min}$ at room temperature. The tissues were washed with another $10 \mathrm{ml}$ of cold quenching buffer, centrifuged at $300 \mathrm{~g}$ for $3 \mathrm{~min}$, and incubated with $2 \mathrm{ml}$ of $25 \%$ Ficoll (Sigma-Aldrich, St Louis, MO, USA; F8016). After addition to a Ficoll gradient of 23,21 and $13 \%$, the tissues were centrifuged at $2500 \mathrm{~g}$ for $20 \mathrm{~min}$ at $4^{\circ}$ C. The islet layer was visible between the 13 and $23 \%$ gradients. The islets were collected and washed with $10 \mathrm{ml}$ of regular cell culture media, centrifuged at $1000 \mathrm{~g}$ for $5 \mathrm{~min}$, and resuspended in $1 \mathrm{ml}$ of RPMI 1640-complete medium (Biowest LLC, Kansas City, MO, USA).

\section{Quantitative RT-PCR analysis}

For most experiments, total RNA was isolated from cells by Trizol (Invitrogen, Carlsbad, CA, USA). A total of $1 \mathrm{mg}$ of RNA was reverse transcribed into cDNA with M-MLV Reverse Transcriptase (Promega, Madison, WI, USA) according to the manufacturer's instructions. PCR was performed with HiFiTaq polymerase (TransGen Biotech, Beijing, China). Quantitative real-time PCR was performed with SYBR Premix Ex Taq (TaKaRa Bio, Kusatsu, Japan) on an ABI 7500 fast real-time PCR system (Applied Biosystems Foster City, CA, USA). Primer sequences are listed in Supplementary Table S1.

\section{Immunofluorescence analysis}

For immunofluorescence staining, iAlpha cells were fixed with $4 \%$ paraformaldehyde for $15 \mathrm{~min}$ at room temperature, and then incubated with PBS containing $0.2 \%$ Triton X-100 (Sigma) for $15 \mathrm{~min}$. Cells were then washed three times with PBS. After blocking with 3\% bovine serum albumin (BSA) in PBS for $60 \mathrm{~min}$ at room temperature, the cells were incubated with primary antibodies diluted in 3\% BSA at $4{ }^{\circ} \mathrm{C}$ overnight, washed three times with PBS, and then incubated with the corresponding fluorescence-labeled secondary antibody diluted in $3 \%$ BSA for $60 \mathrm{~min}$ at room temperature in the dark. Nuclei were stained with DAPI (Sigma). The primary antibodies used in this experiment were as follows: mouse anti-glucagon (Millipore, Billerica, MA, USA), mouse anti-IRX2 antibody (1:500, Abcam, Cambridge, 
UK), rabbit anti-Dpp4 antibody (1:400, Abcam), and rabbit anti-Arx antibody (1:300, Millipore). The secondary antibody used was as follows: Cy3-conjugated goat anti-mouse IgG (Jackson Laboratories, Farmington, CT, USA; 1:1000), goat anti-mouse IgG (1:500, Abcam), Alexa Fluor 647-conjugated goat anti-rabbit IgG, and Alexa Fluor 647 (1:500, Abcam).

\section{Enzyme-linked immunosorbent assay (ELISA)}

To determine the extent of insulin and glucagon secretion, TTFs transduced with five transcription factors were cultured in medium without phenol red. After stimulation with $15 \mathrm{~mm}$ glucose, $30 \mathrm{~mm} \mathrm{KCl}$ and $15 \mathrm{~mm}$ arginine for different times, culture supernatant was collected. The amount of glucagon and insulin in the supernatant was determined by the mouse glucagon and insulin ELISA kits, respectively (Alpco Diagnostics, Salem, NH, USA), according to the manufacturer's instructions.

\section{Microarray analysis}

Total RNA extracted from $p 19^{A r f-/-}$ TTFs, $p 19^{A r f-/-}$ islets cultured for 6 days, and 5TF-transduced $p 19^{A r f-/-}$ TTFs from different experiments were hybridized to whole mouse gene expression microarrays (Agilent, Santa Clara, CA, USA) under the manufacturer's instruction. Data were normalized by Gene-Spring (Agilent). Microarray hybridization and analysis were carried out by ShanghaiBio Cooperation. Out of 43400 annotated genes, 3942 genes for which expression levels were at least five-fold different between $p 19^{A r f-/-}$ TTFs and primary islets were selected for analyses. Hierarchical clustering of samples was performed by Cluster 3.0 software. Average linkage with the uncentered correlation similarity metric was used for the clustering of samples. Original data were uploaded to the Gene Expression Omnibus database.

\section{Insulin tolerance test}

After a 3-h fast, human insulin 100 (Eli Lilly and Company, Indianapolis, IN, USA; $1 \mathrm{IU} \mathrm{kg}^{-1}$ ) was administered by intravenous injection to the mice, and blood glucose levels were measured using an Accu-Chek Inform Blood Glucose Monitoring System (Roche Diagnostics, Indianapolis, IN, USA).

\section{Glucose tolerance test}

After a 12-h fast, glucose $\left(1 \mathrm{~g} \mathrm{~kg}^{-1}\right)$ was administered intraperitoneally (i.p.) to mice, and the blood glucose level was measured using an Accu-Chek Inform Blood Glucose Monitoring System (Roche Diagnostics).

\section{Immunohistochemistry analysis}

Paraffin-embedded pancreatic sections of $4-\mu \mathrm{m}$ thickness were deparaffinized in xylene and rehydrated in graded alcohols. Slides were treated with periodic acid for $10 \mathrm{~min}$ at room temperature, after which they were incubated in 5\% normal serum for $1 \mathrm{~h}$ at room temperature in a moist chamber. For immunohistochemical staining of glucagon, insulin and Ki67, a polyclonal rabbit anti-glucagon antibody (Millipore; 1:100), rabbit anti-mouse insulin antibody (Millipore; 1:200), or rabbit anti-mouse anti-Ki67 antibody (Abcam; 1:2000) served as the primary antibodies. The secondary antibody was an HRP-conjugated goat anti-rabbit IgG antibody (Dako, Glostrup, Denmark) diluted 1:100. All antibodies were diluted in 0.5\% BSA. Reactivity was visualized via the DAB Liquid System (Dako), according to the manufacturer's instructions. Sections were counterstained with hematoxylin.
For determining the proportion of $\alpha$ - and $\beta$-cells as well as the proportion of replicating cells, the percentage of glucagon-, insulin-, and Ki67-positive cells were determined in seven sections and quantified using ImagePlus software.

\section{Tumor generation assay}

The human pancreatic tumor cell line, $\alpha$-TC, was cultured in the same medium as the iAlpha cells. iAlpha cells were induced and enriched as described above. After 28 days induction, the cells were detached by trypsin and suspended in PBS. Seven nude mice were injected with $5 \times 10^{6}$ iAlpha cells and $\alpha$-TC cells in the kidney. Tumor numbers were counted 4 weeks after injection.

\section{Statistical analysis}

All data are presented as mean and standard deviations (s.d.s). For most statistical evaluations, an unpaired Student's $t$-test was applied for calculating statistical probability in this study. One-way analysis of variance with post hoc tests adjusted by the Bonferroni method were performed for group comparisons if there were $\geqslant 3$ groups. Statistical calculations were performed using Statistical Program for Social Sciences software (SPSS, IBM, Amon, NY, USA). For all analyses, data from at least three independent samples or repeated experiments were used.

\section{RESULTS}

\section{Transcription factors induce $\alpha$-cell conversion from iHep} or TTFs

Previous studies suggest that cell reprogramming could be more successful if the starting cell type shares a common developmental lineage with the desired cell type. ${ }^{25}$ Hepatocytes and pancreatic endocrine cells share a common progenitor cell during embryonic development, ${ }^{26}$ and hepatocytes have been reprogrammed to insulin-positive cells by forced expression of $P d x 1$ in vivo. ${ }^{27}$ However, it remains unclear whether hepatocytes could be converted into specific endocrine cells in vitro. Thus, we first examined the reprogramming potential of iHep cells, which were induced from mouse TTFs by overexpression of Gata4, Hnf1a and Foxa3 and the inactivation of p19 ${ }^{A r f} \cdot{ }^{17,28}$ Importantly, iHep cells show an expression profile and hepatic function close to those of mature hepatocytes. ${ }^{17}$ We first screened 11 pancreatic transcription factors for their ability to induce endocrine cells (Figure 1a, Supplementary Table S2). Insulin (Ins2) and glucagon ( $G c g$ ) expression at day 7 following the lentiviral-mediated overexpression of individual pancreatic transcription factors was determined. As shown in Figure 1b, the mRNA levels of glucagon ( $\alpha$-cell-specific) but not Ins ( $\beta$-cell-specific) were largely induced following Pdx1, Hhex and Pax4 overexpression (all $P<0.01$ ), indicating that iHep cells can be converted to glucagon-producing cells. The murine islet group served as the positive control. Next, iHep cells were transduced with the combination of Pdx1, Hhex and Pax4 to enhance such conversion. Expression of glucagon was significantly increased at days 5-9 following overexpression of $P d x 1$, Hhex and Pax4 $(P<0.01$; Figure 1c). Moreover, another $\alpha$-cell-specific marker gene, Arxin (Arx), was also significantly increased at days 2-9 compared with Day $0 \quad(P<0.01$; Figure 1c). Morphologically, the iHep cells converted from a 
a
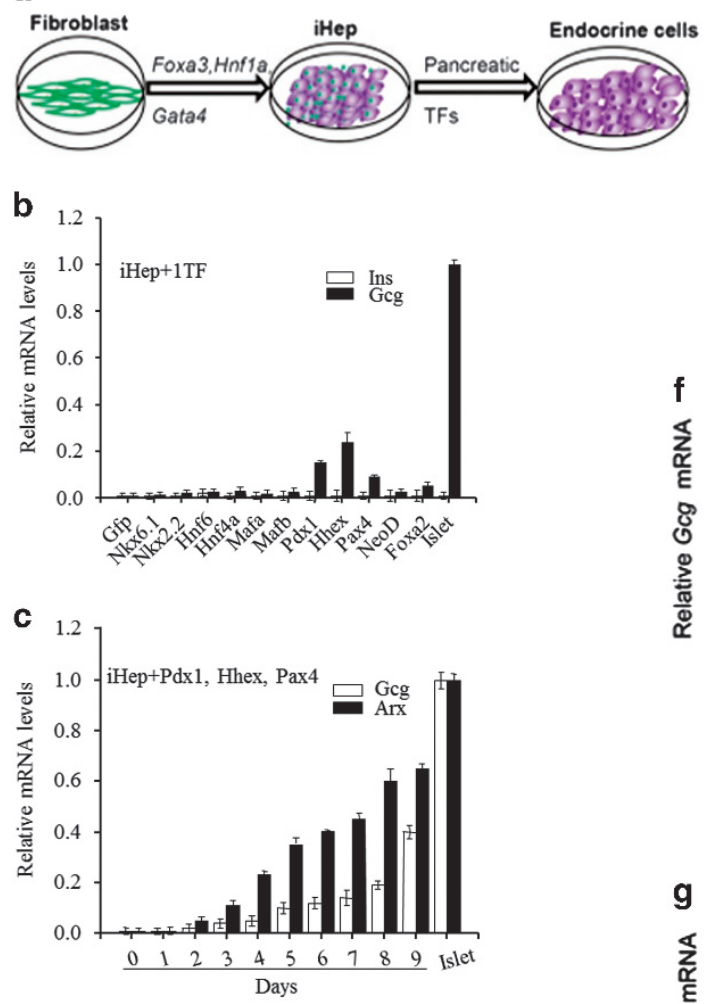

d

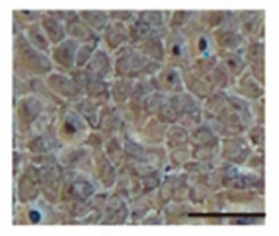

iHep

f

g e

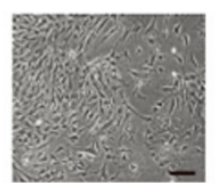

TTF-GFP

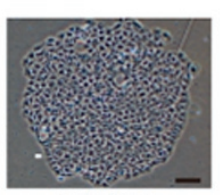

TTF-6TF h
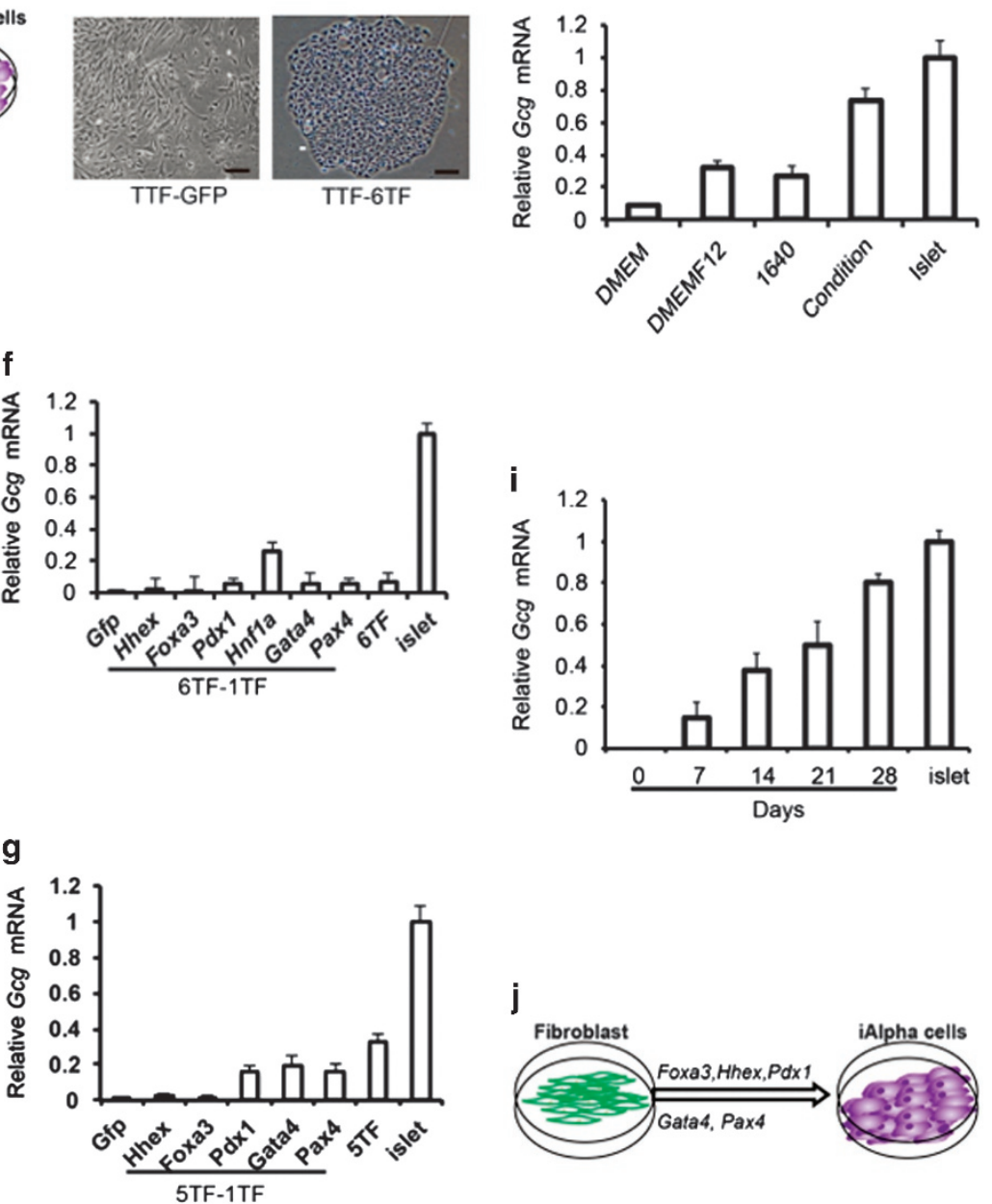

j

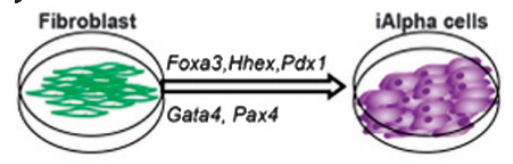

Figure 1 Transcription factors induce the conversion of iHEP and tail-tip fibroblasts (TTFs) into $\alpha$-cells. (a) Experimental design of iAlpha cell induction. iHEP were infected with lentiviruses expressing endocrine transcription factors. Cultures were changed from modified Block's medium to DMEM medium 2 days after infection. (b) After 7 days following transduction, expression of insulin (Ins2) and glucagon (Gcg) were measured by RT-PCR. (c) Gcg and Arx levels were determined over time by RT-PCR in screened iHep cells tranduced with Pdx1, Hhex and Pax4. (d) iHEP cells had epithelial morphology while those transduced with Pdx1, Hhex and Pax4 displayed a mesenchymal-like morphology. scale bars: $100 \mu \mathrm{m}$. (e) Clone formation by TTFs following transduction with 6TFs. scale bars: $50 \mu \mathrm{m}$ (f) Gcg expression after removal of individual factors from the 6TF combination. (g) Effect of Gcg expression after removal of individual factors from the 5TF combination. (h) Expression of Gcg by cells transduced with 5TF and cultured in different media was analyzed by RT-PCR. (i) Expression of Gcg by cells transduced with 5TF was monitored up to 28 days by RT-PCR during the induction of iAlpha cells by 5TF. (j) Experimental design of iAlpha cell induction from TTF with the 5TF combination (iHEP factors: Gata4, Hnfla, Foxa3 and screened factors: Pdx1, Pax4 and Hhex). (f-i) All data are presented as mean \pm s.d. (b,c,f-i) Gfp was the vector control, and islets were the positive control.

typical epithelial-like morphology to pseudo-epithelial-like after $P d x 1$, Hhex and Pax4 overexpression (Figure 1d).

Since iHep cells were derived from TTFs, we next determined whether glucagon-producing cells could be acquired directly from TTFs following overexpression of the iHep induction factors, Gata4, Hnfla and Foxa3, with $P d x 1$, Hhex, Pax4 (collectively referred as 6TF) in $p 19^{A r f-/-}$ TTFs, which could form clones after 14 days (Figure 1e). As shown in Figure 1f, glucagon mRNA expression was detected following overexpression of the 6TFs (Figure 1f). We next removed individual factors from the $6 \mathrm{TF}$ combination and examined glucagon expression, which increased upon the removing of
Hnfla $(P<0.01$; Figure 1f). Hence, we transduced TTFs with Gata4, Pdx1, Hhex, Pax4 and Foxa3 (collectively referred to as 5TF) as removal of any transcription factor from 5TF significantly reduced glucagon expression $(P<0.05$; Figure $1 \mathrm{~g}$, Supplementary Figure S1a). Although overexpression of Hhex and Foxa3 were sufficient to induce glucagon expression (Supplementary Figure S1d), mRNA levels of glucagon and Arx were significantly lower in Hhex- and Foxa3-induced cells than observed in 5TF-transduced cells (Supplementary Figure S1b). Protein levels of glucagon were also expressed at a low level in Hhex- and Foxa3-induced cells compared with iAlpha cells (Figure 2a). 
a

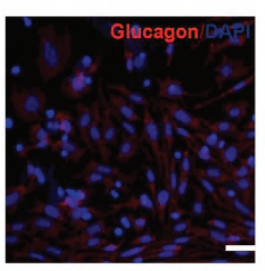

Hhex,Foxa3

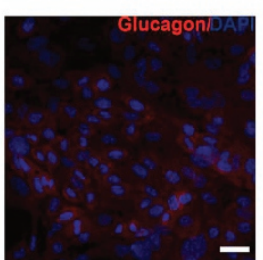

Hhex,Foxa3,Gata4

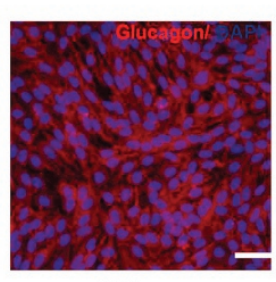

5TFs

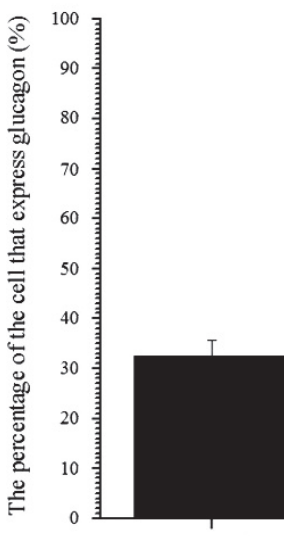

Hex, Foxa3

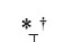

$*+$

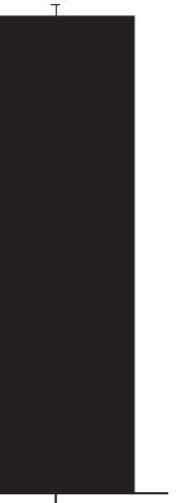

5TFs

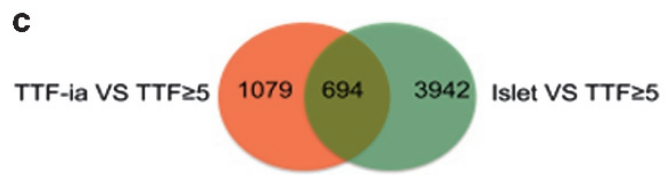

Total genes: $43400 \quad P=3.24 E-20$

b

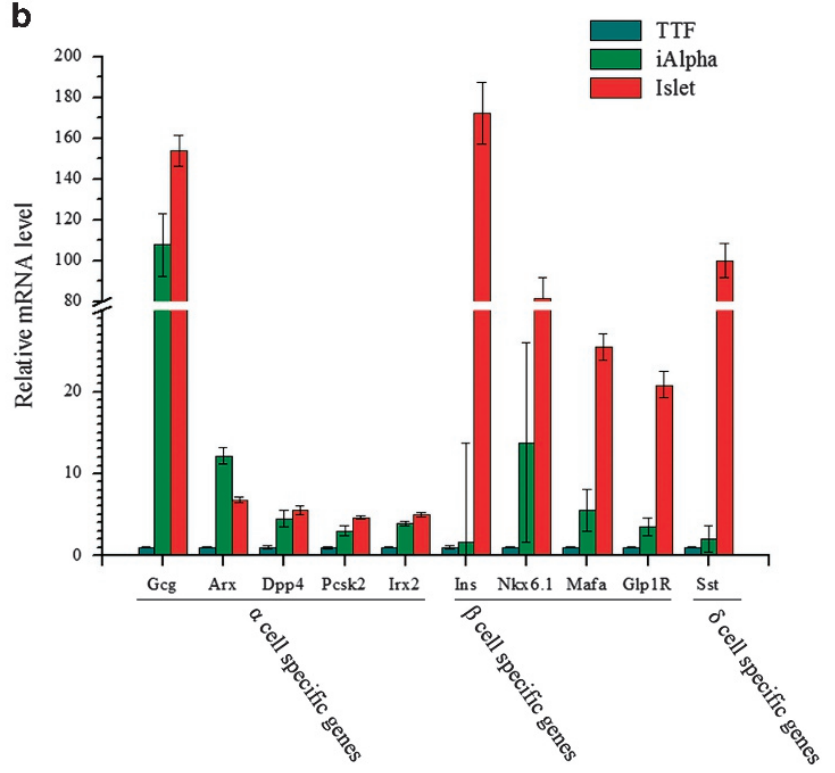

d

\begin{tabular}{|l|r|r|}
\hline Pathway $P$ value & islet vs TTF & TTFiavsTT \\
\hline Cell Communication & $1.93 \mathrm{E}-55$ & $2 \mathrm{E}-20$ \\
\hline Neuroactive ligand-receptor interaction & $2.64 \mathrm{E}-49$ & $7.9 \mathrm{E}-33$ \\
\hline Focal adhesion & $7.17 \mathrm{E}-46$ & $7.4 \mathrm{E}-19$ \\
\hline Cell adhesion molecules (CAMs) & $7.34 \mathrm{E}-39$ & $1.5 \mathrm{E}-23$ \\
\hline ECM-receptor interaction & $1.65 \mathrm{E}-38$ & $2.5 \mathrm{E}-12$ \\
\hline MAPK signaling pathway & $1.13 \mathrm{E}-36$ & $1.8 \mathrm{E}-24$ \\
\hline Maturity onset diabetes of the young & $5.22 \mathrm{E}-36$ & $5.1 \mathrm{E}-06$ \\
\hline Cytokine-cytokine receptor interaction & $5.22 \mathrm{E}-36$ & $1.4 \mathrm{E}-32$ \\
\hline Calcium signaling pathway & $3.46 \mathrm{E}-33$ & $1.1 \mathrm{E}-19$ \\
\hline Regulation of actin cytoskeleton & $1.40 \mathrm{E}-28$ & $1.1 \mathrm{E}-19$ \\
\hline Complement and coagulation cascades & $1.08 \mathrm{E}-23$ & $5.6 \mathrm{E}-20$ \\
\hline Hematopoietic cell lineage & $2.61 \mathrm{E}-19$ & $9.7 \mathrm{E}-11$ \\
\hline Leukocyte transendothelial migration & $3.97 \mathrm{E}-19$ & $6.1 \mathrm{E}-19$ \\
\hline Arachidonic acid metabolism & $7.47 \mathrm{E}-17$ & $3.2 \mathrm{E}-09$ \\
\hline Axon guidance & $9.59 \mathrm{E}-17$ & $2 \mathrm{E}-20$ \\
\hline Tight junction & $2.48 \mathrm{E}-16$ & $3.3 \mathrm{E}-16$ \\
\hline Long-term depression & $1.26 \mathrm{E}-15$ & $8.3 \mathrm{E}-15$ \\
\hline Wnt signaling pathway & $2.99 \mathrm{E}-14$ & $2.7 \mathrm{E}-15$ \\
\hline Melanogenesis & $3.33 \mathrm{E}-14$ & $7.9 \mathrm{E}-15$ \\
\hline
\end{tabular}

Figure 2 iAlpha cells transduced with five pancreatic cell transcription factors stably express $\alpha$-cell functional genes and transcription factors. (a) Gcg immunostaining and morphological changes induced by different transcription factor combinations. The bottom panel shows the data following quantification. ${ }^{\star} P<0.05$, significantly different with Hex, Foxa3; ${ }^{\dagger} P<0.05$, significantly different with Hex, Foxa3, Gata4. (b) Expression of $\alpha$-, $\beta$ - and $\delta$-cell-specific genes in TTFs, iAlpha cells and islet cells (positive control) were measured by RT-PCR 4 weeks after induction. Data are presented as mean \pm s.d. (c) Overlap of islet- and TTF-ia-enriched genes. The selected levels were islet/TTF $>5$ and TTF-ia/TTF $>5$. There was significant overlap between islet and TTF-ia gene expression. (d) Pathway analysis. For the 20 pathways which mostly active in islet, there were 17 overlap pathways in TTF-ia, and the other three pathways were also significantly different compared with that in TTFs (red).

To determine the impact of each transcription factor in the 5TF combination in induction, we monitored the expression of lineage-specific markers after removing individual factors from 5TF. As shown in Supplementary Figure S1c, expression of endoderm markers (Emoes, Wnt3a, and Gata6), a pancreatic progenitor marker (Sox9), a liver-specific marker (Alb), a $\beta$-cell-specific marker (Mafa), a $\delta$-cell-specific marker (sst) and an exocrine cell-specific marker (Amy2) was altered following the withdrawal of any factor from 5TF.

Previous studies have shown that culture conditions are critical for endocrine cell differentiation in vitro. ${ }^{29}$ One conditional medium, which contained neural basal medium, $\mathrm{N}-2$ supplement, B-27 supplement, nicotianamine and basic fibroblast growth factor (bFGF), was more potent in inducing glucagon expression than DMEM, RPMI1640, or DMEM-F12 media $(P<0.01$; Figure 1h). Analysis of the expression of glucagon revealed that it increased gradually over time and was significantly greater at days 14-28, suggesting that the conversion is a progressive process $(P<0.01$; Figure 1i). Taken together, TTFs are converted into glucagon-producing cells with 5TF overexpression and culture in neural-basal medium-based conditional medium for 28 days (Figure 1j; Supplementary Figure S1e). 

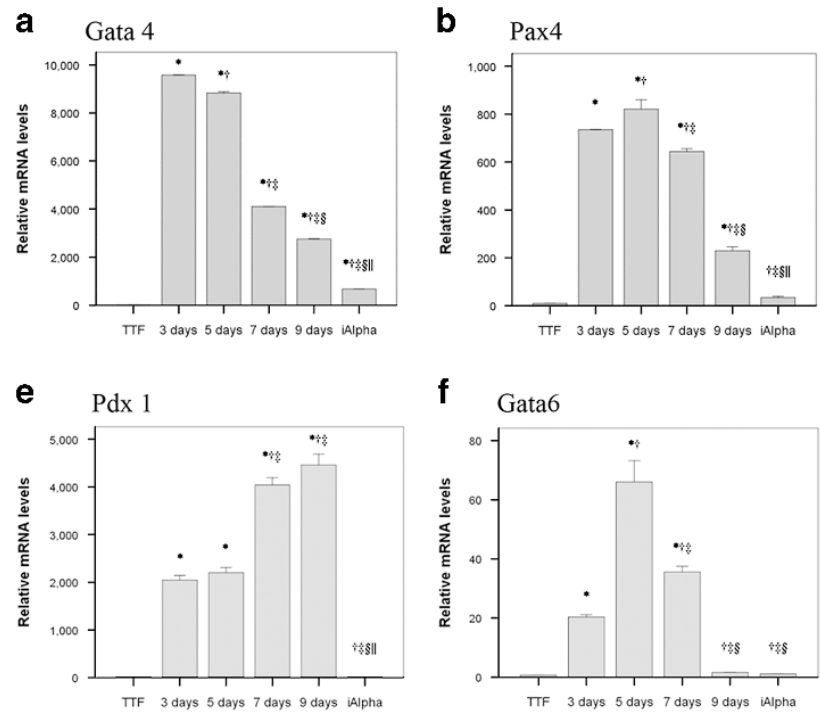

* $p<0.05$, significantly different with TTF; $\uparrow p<0.05$, significantly different with 3 days

$\mathrm{p}<0.05$, significantly different with 5 days; $\S \mathrm{p}<0.05$, significantly different with 7 day

$\mathrm{p}<0.05$, significantly different with 9 days

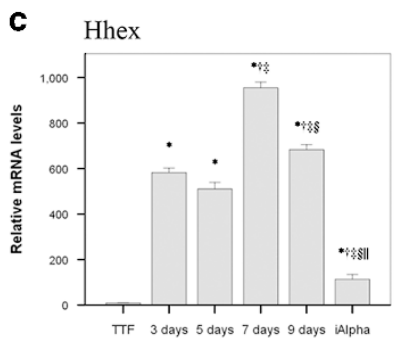

d Foxa 3
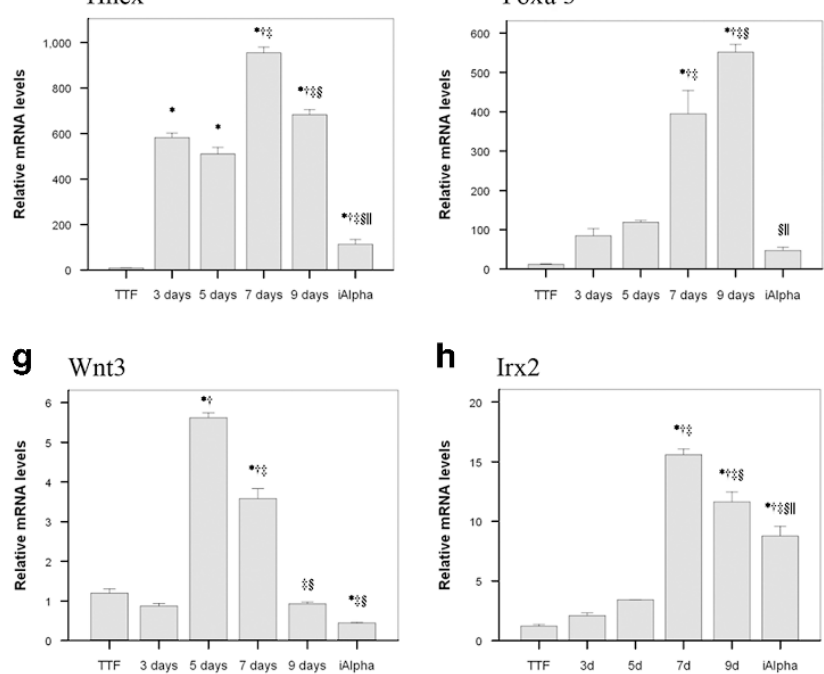

h $\quad$ Irx2

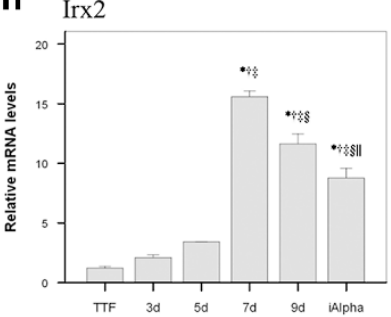

Figure 3 Dynamic changes in the expression of five pancreatic cell transcription factors and lineage-specific genes. (a-e) Expression of the 5TFs during TTF induction. ( $\mathbf{f}-\mathbf{h})$ Dynamic changes of endoderm markers (Gata6 and Wnt3a) and a mature $\alpha$-cell marker (Irx2) over time. Data are presented as mean \pm s.d. ${ }^{*} P<0.05$, significantly different with $\mathrm{TTF} ;{ }^{\dagger} P<0.05$, significantly different with 3 -day values; ${ }^{\ddagger} P<0.05$, significantly different with 5 -day values; ${ }^{\S} P<0.05$, significantly different with 7 -day values; $" P<0.05$, significantly different with 9 -day values.

iAlpha cells transduced by 5 TF stably express $\alpha$-cell-specific genes and transcription factors

To determine the extent to which the iAlpha cells express glucagon, immunofluorescence analysis was conducted. As shown in Figure 2a, virtually every cell in the 5TFs group expressed glucagon. To further characterize the glucagonproducing iAlpha cells, we analyzed the expression of $\alpha$-cell-specific transcription factors, including Arx, Dpp4, Pcsk2 and Irx2. The mRNA expression of the $\alpha$-cell-specific transcription factors was significantly higher in iAlpha cells compared with TTFs $(P<0.001$; Figure 2b). Notably, the expression of marker genes for other pancreatic cells, such as Ins, Nkx6.1 and Glp1R ( $\beta$-cells), Sst ( $\delta$-cells), were similar in iAlpha cells and TTFs $(P>0.05$; Figure $2 \mathrm{~b})$. Furthermore, the expression of the $\delta$ cell-specific gene, Sst, was 50 -fold lower in iAlpha cells than in the islet control. Moreover, the expression of the $\beta$ cell-specific gene, insulin, was 100-fold lower in iAlpha cells than in the islet controls. These data indicated that the induced iAlpha cells were nearly monohormonal. Finally, expression of the $\alpha$-cell-specific genes, Arx, Dpp4 and Irx2, by iAlpha cells was confirmed by immunofluorescence analysis (Supplementary Figure S1f).

We next compared the global expression profiles among iAlpha cells, TTFs, and islets. Along with in vitro proliferation (Supplementary Figure S2a), numerous islet-specific genes were upregulated in iAlpha cells compared to TTFs (Figure 2b, Supplementary Figures S2b and c). In addition, microarray analysis revealed that 1079 and 3942 annotate genes out of 43400 were upregulated by five-fold in iAlpha cells and islets, respectively, and 694 of these were upregulated in both (Figure 2c). Figure 2d shows the results of pathway analysis; there were 17 pathways were both activated in iAlpha cells and islet, out of the 20 pathways activated in islet. Taken together, these data suggest that TTFs were converted into $\alpha$-like cells (iAlpha cells), but not to other pancreatic lineage cells.

\section{Dynamic changes in lineage-specific gene expression following 5TF transduction}

To assay the stability of conversion, we firstly analyzed the dynamic changes in the expression of the five transcription factors used for iAlpha cell transduction (Figures 3a-e). The mRNA expression of Pax4 and Hhex were initially elevated, peaking at days 5 and 7 as compared with the other time points analyzed (all $P \leqslant 0.001$; Figures $3 \mathrm{~b}$ and c). The expression levels of the transcriptional factors, Foxa3 and Pdx1, increased with time during the induction period. Although the expression levels of all five transcriptional factors decreased in iAlpha cells, Gata4, Hhex, Pax4 and Foxa3 were higher in iAlpha cells as compared to TTFs $(P<0.001)$. However, the expression level of Pdx1 was similar between in iAlpha cells and TTFs (Figure 3e). Next, we analyzed the dynamic changes of the endoderm markers, Gata6 and Wnt3a (Figures $3 \mathrm{f}$ and g). The mRNA expression of Gata6 and Wnt3a was significantly higher at day 5 as compared with the other time points analyzed (all $P \leqslant 0.001$; Figures $3 \mathrm{f}$ and g). In iAlpha cells, Gata6 and Wnt3 levels were reduced as compared to the induction phase; however, Gata6 levels were higher than that observed in TTFs. Wnt3a levels were lower in iAlpha cells than in TTFs. We also analyzed the mRNA expression level of a mature $\alpha$-cell marker, Irx2, during induction; Irx2 was significantly higher at day 7 (all $P \leqslant 0.001$; Figure $3 \mathrm{~h}$ ). Irx2 levels were significantly higher in iAlpha cells than in TTFs. 
a

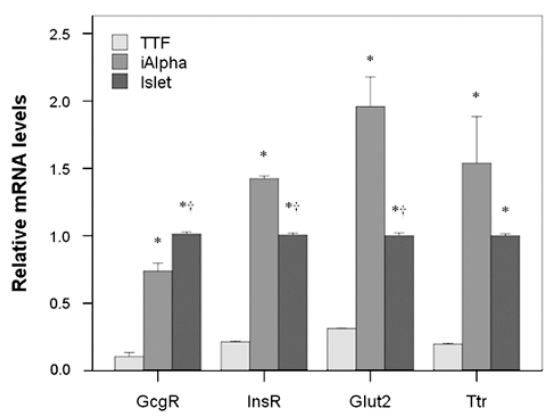

d

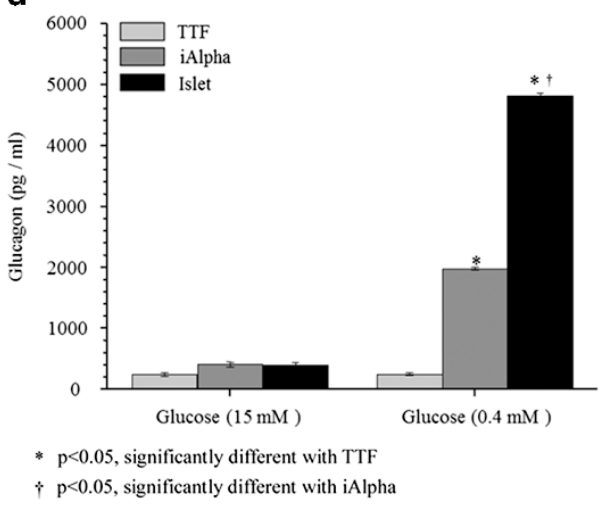

b

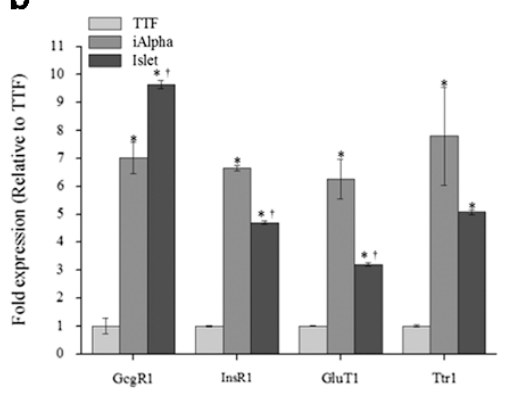

C

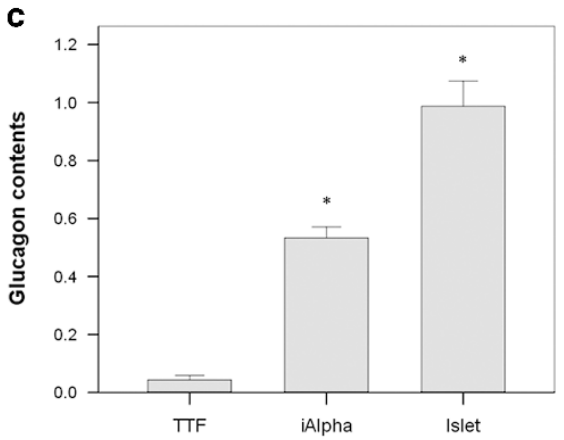

e

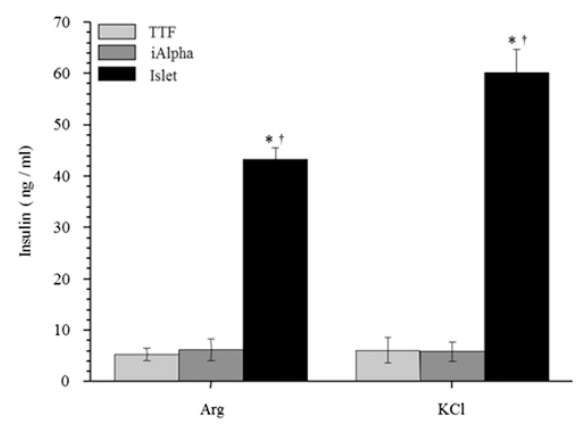

Arg

$\mathrm{KCl}$

Figure 4 Characterization of iAlpha cells in vitro. (a) Expression of $\alpha$-cell-specific genes (i.e., Gcgr, Insr, Glut2 and Ttr) were analyzed by RT-PCR and (b) normalized to that observed in TTFs. (c-e) Glucagon and insulin content were analyzed by ELISA. (c) Basal glucagon production. (d) Glucagon secretion from mouse islets, TTFs and iAlpha cells in response to 0.4 or $15 \mathrm{~mm}$ glucose. (e) Insulin secretion kinetics from mouse islets, TTFs and iAlpha cells in response to $30 \mathrm{~mm} \mathrm{KCl}$ or $15 \mathrm{~mm}$ arginine. Data are presented as mean $\pm \mathrm{s}$.d. ${ }^{*} P<0.05$, significantly different from TTFs; ${ }^{\dagger} P<0.05$, significantly different from iAlpha cells.

\section{Characterization of iAlpha cell function in vitro}

The receptors of glucose and insulin as well as glucagon transporters in $\alpha$-cells are critical for glucagon sensing and secretion. ${ }^{30}$ Analysis of their expression in iAlpha cells revealed that glucagon transporter, InsR, Glut2 and transthyretin (Ttr) mRNA expression was significantly higher in iAlpha cells compared with TTFs (all $P \leqslant 0.008$; Figures $4 \mathrm{a}$ and b). In addition, the glucagon content was significantly higher in iAlpha cells and islets compared with TTFs $(P<0.001$; Figure 4c); however, the insulin levels were significantly higher in the islet group compared with TTFs and iAlpha cells $(P<0.001$; Figure 2b).

Analysis of glucagon secretion showed that it was significantly increased in iAlpha cells and islets in response to $0.4 \mathrm{~mm}$ glucose as compared to TTFs (all $P \leqslant 0.02$ ); no differences were observed with $15 \mathrm{~mm}$ glucose (Figure $4 \mathrm{~d}$ ). However, increased insulin secretion was only observed in the islet group in response to KCI and Arg (all $P<0.001$, Figure 4e).

\section{Characterization of iAlpha cells in vivo}

To verify the physiologic function of iAlpha cells, their sensitivity to stimuli was tested in nude mice that were transplanted with $1 \times 10^{6}$ iAlpha cells or TTFs in the kidney capsule. Body weight, ITT and GTT outcomes were measured at 2, 4 and 8 weeks after transplantation. At 2 weeks, there was no significant difference between body weights of nude mice transplanted with TTFs or iAlpha cells $(P>0.05$, Figure 5a). In contrast, at 4 weeks, the body weights of the mice transplanted with iAlpha cells were significantly decreased compared with those receiving TTF transplantation $(P=0.007$, Figure $5 \mathrm{~d})$; however, they were recovered at 8 weeks $(P>0.05$, Figure $5 \mathrm{~g})$.

At 2 weeks, delayed blood glucose level reductions were found by ITT (Figures 5b and c). Specifically, at 0 and $30 \mathrm{~min}$, the mean glucose level by ITT was significantly higher in iAlpha cells than in TTFs $(P \leqslant 0.016$, Figure $5 \mathrm{~b})$. At 4 weeks, ITT showed that there were significant differences in iAlphaand TTF-transplanted mice at 0 and $30 \mathrm{~min} \quad(P \leqslant 0.01$, Figure 5e). Furthermore, GTT showed that the glucose levels were higher in mice transplanted with iAlpha cells as compared to those receiving TTFs at $0 \mathrm{~min}(P=0.01$, Figure $5 \mathrm{f})$. However, at 8 weeks, there was no significant difference of ITT and GTT between the groups (Figures $5 \mathrm{~h}$ and i). Therefore, iAlpha cell transplantation can disturb in vivo blood glucose regulation.

\section{iAlpha cells induce the regeneration of islet cells}

The function of iAlpha cells were decreased at 8 weeks after transplantation. To uncover the reason for this decreased function, we first examined the survival of iAlpha cells in the recipients, and observed the graft in the capsule of recipient's kidney (Figure 6a). In addition, these cells were glucagonpositive (Figure 6b). Thus, at 8 weeks, iAlpha cells do not 

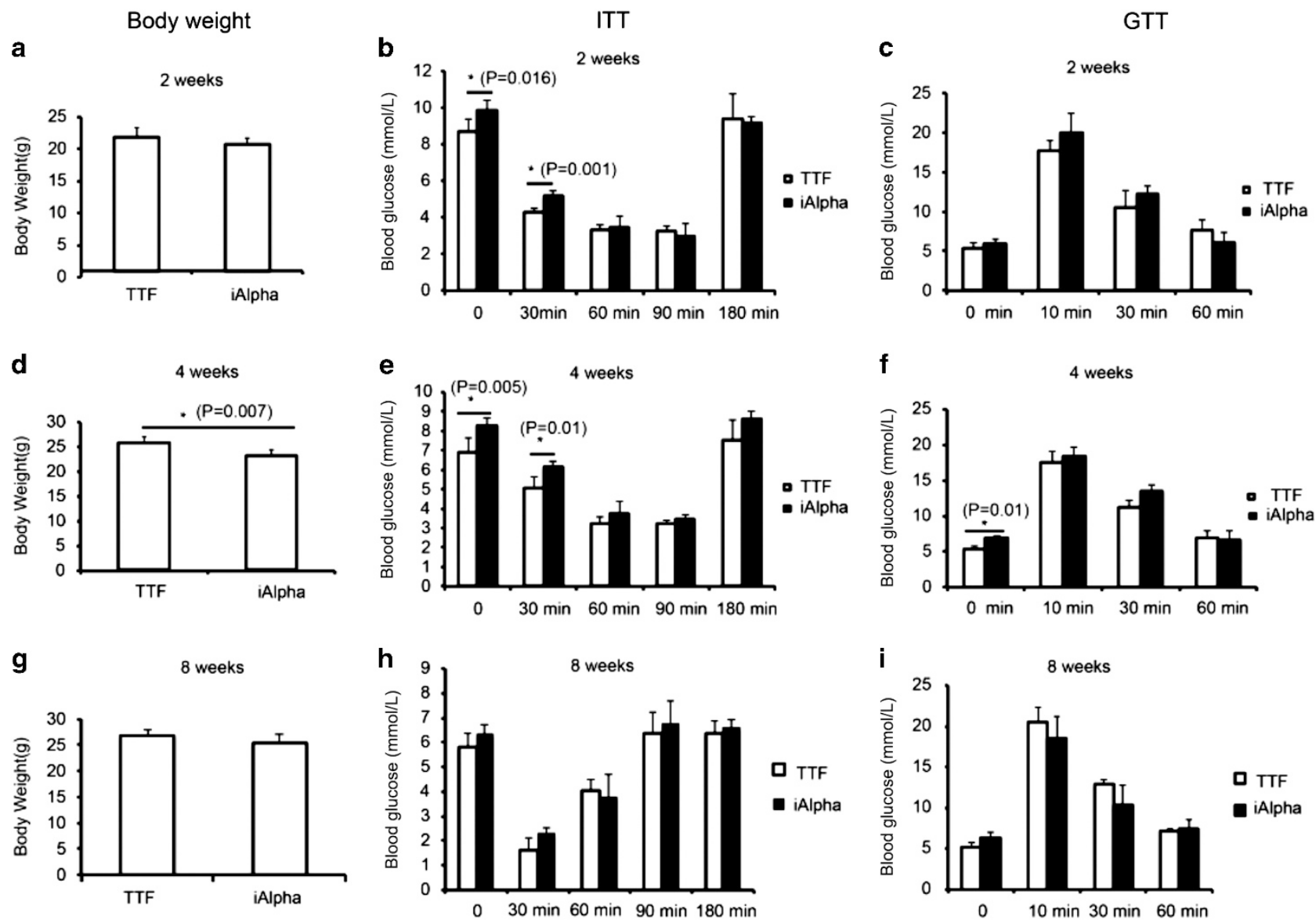

Figure 5 Characterization of iAlpha cells in vivo. (a,d,g) Body weights of nude mice transplanted with TTFs $(n=7)$ and iAlpha cells $(n=5)$ after (a) 2, (d) 4, or (g) 8 weeks. (b,e,h) ITT of nude mice transplanted with TTFs $(n=7)$ and iAlpha cells $(n=5)$ after (b) 2, (e) 4 , or (h) 8 weeks. Insulin was intravenously injected $\left(1 \mathrm{U} \mathrm{kg}^{-1}\right)$. (c,f,i) GTT test of nude mice transplanted with TTFs $(n=7)$ and iAlpha cells $(n=5)$ after (c) 2, (f) 4 , or (i) 8 weeks, Glucose $\left(100 \mu \mathrm{g} \mathrm{kg}{ }^{-1}\right)$ was intraperitoneally injected. ${ }^{*} P<0.05$.

appear to have an important role in regulating glucose. We detected the plasma levels of insulin and glucagon in the recipient mice, and found that both glucagon and insulin levels were higher in the iAlpha recipients as compared to those in the TTF recipients at 8 weeks (both $P<0.05$; Figures $6 \mathrm{c}$ and d). These data suggest that iAlpha cell transplantation disturbs islet function.

We next detected islet changes following iAlpha cell transplantation. As shown in Figure 6e, the proportion of Ki67-positive cells as well as Ins-positive cells ( $\beta$-cells) in the islets of the iAlpha cell recipients were higher than that observed in TTF recipients (Ki67, $4.67 \% \pm 1.65$ vs $0.79 \% \pm 0.81$, respectively; Ins, $72.89 \% \pm 0.76$ vs $46.57 \% \pm 0.92$, respectively; both $P<0.05)$; however, the proportion of glucagon-positive cells $(\alpha$-cells $)$ in the islet was decreased $(12.45 \% \pm 0.56$ vs $19.57 \% \pm 0.41$, respectively; $P<0.05$ ). These results demonstrate iAlpha cells decrease the ratio of $\alpha$-to- $\beta$ cells in recipient islets, which may be due to transdifferentiation of the $\alpha$-cells to $\beta$-cells in the islet. Remarkably, iAlpha cells do not form tumors 8 weeks after transplantation in nude mice, while $\alpha$-TC cells, an $\alpha$ tumor cell line, form tumors (Supplementary Figure S3a), Moreover, iAlpha cells in the graft are
PCNA-negative (Supplementary Figure S3b), suggesting that they are unlikely to induce tumor formation.

\section{DISCUSSION}

In addition to maintaining plasma glucose levels, $\alpha$-cells may also protect and transdifferentiate into new $\beta$-cells. However, the possibility and mechanism has remained controversial due to the absence of an in vitro model, as it is not easy to purify $\alpha$-cells in vitro. In the present study, we experimentally demonstrate a protocol to generate $\alpha$-like cells (iAlpha cells) using TTFs overexpressing five transcription factors and cultured in conditional medium. Induced cells could express the $\alpha$-cell markers, glucagon and Arx, in addition, transplantation of iAlpha cells into the kidney capsule disturbed the metabolism of the recipient, inducing insulin resistance and promoting $\beta$-cell proliferation. Taken together, the new iAlpha cells possess many of the characteristics of primary $\alpha$-cells.

For many years, it was thought that terminally differentiated cells were committed to a specific function and could no longer change their identity. In contrast, progenitor/stem cells are expected to retain some multipotency capacities, and therefore, may be more suitable for tissue replacement strategies. However, ES/iPS-derived endocrine cells are usually 
a

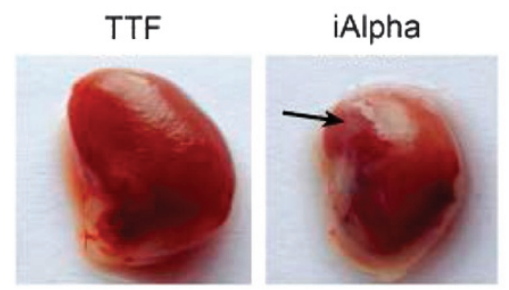

C

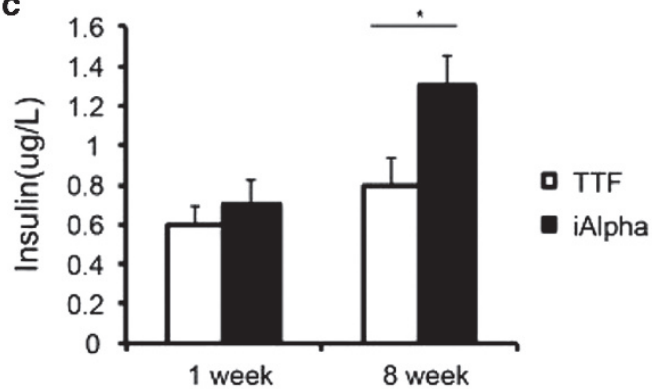

d

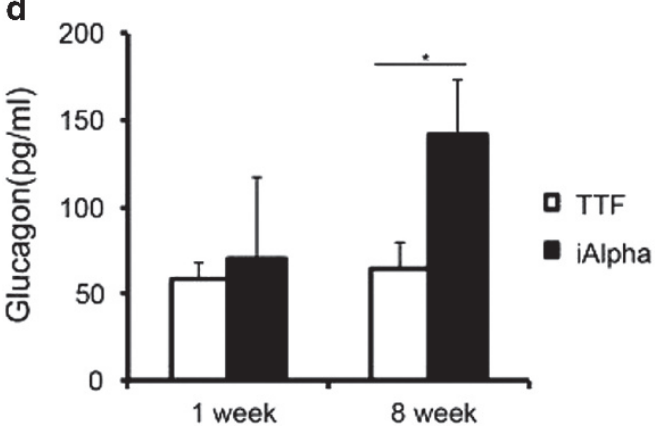

b
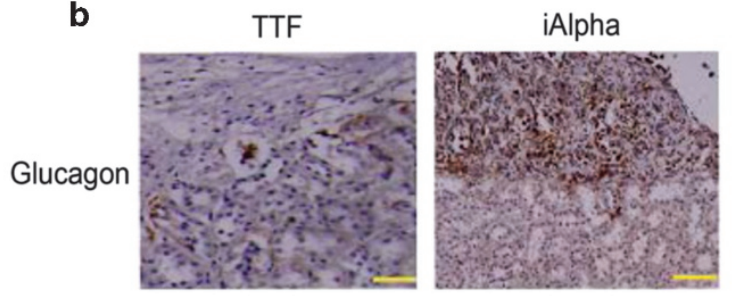

e

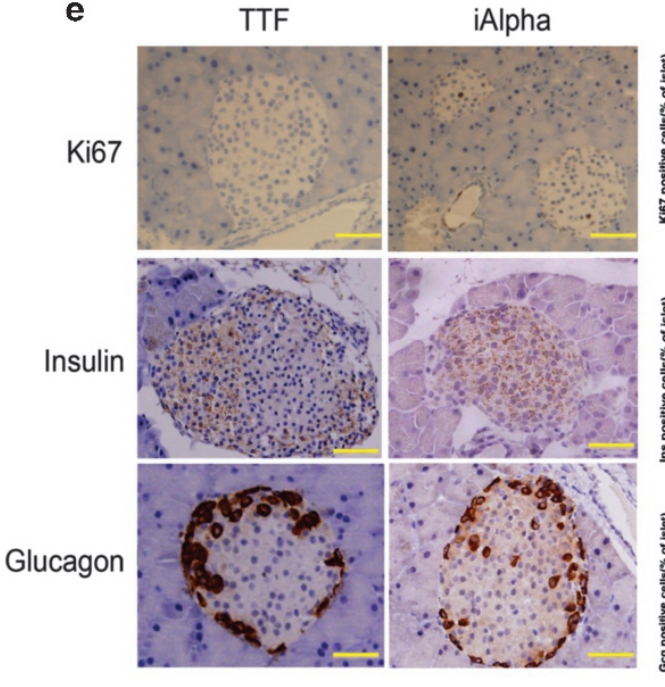

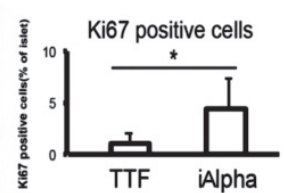
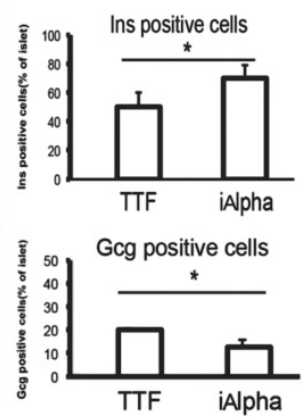

Figure 6 iAlpha cells induce the regeneration of islet cells. (a) iAlpha cell grafts could be visualized in the kidney capsule. (b) iAlpha cell survival in the kidney capsule was confirmed by immunohistochemistry analysis for glucagon expression (brown staining). (c) Plasma insulin and (d) plasma glucagon at 1 and 8 weeks following cell transplantation as determined by ELISA. Data are mean + s.d. ${ }^{*} P<0.05$. (e) Representative images of Ki67, insulin and glucagon staining in murine pancreatic tissues following TTF or iAlpha cell transplantation ( $n=3$ mice). Data are mean + s.d. ${ }^{*} P<0.05$.

bi-functional, coexpressing both insulin and glucagon and thereby impairing glucose sensing. Moreover, the limited availability of islets and ES/iPS-derived endocrine cells has restricted the development of cell-based replacement therapies for diabetes. Thus, identifying a new resource of islet cells, which include both $\alpha$ - and $\beta$-cells, is crucial. Reprogramming of islet cells from somatic cells may represent an alternative method to obtain these cells. Although efficient 'transdifferentiation' has been shown in the absence of a pluripotent state, reprogrammed endocrine cells have not been previously generated in vitro. Here, we successfully convert fibroblasts into endocrine cells by overexpression of endocrine lineagespecific transcription factors. Such conversion avoids an intermediate pluripotent state and essentially removes the risk of teratoma formation. Expression of the $\alpha$-cell-specific marker, glucagon, was drastically induced in TTFs overexpressing the 5TFs. Furthermore, the generated iAlpha cells exhibited a mature $\alpha$-cell phenotype resembling that of primary cells.

In a healthy individual, $\alpha$ - and $\beta$-cells mutually regulate each other. Low levels of serum glucose will stimulate $\alpha$-cells to secret glucagon. Upon glucagon secretion, serum glucose level will rise, stimulating $\beta$-cells to secret insulin. Furthermore, high levels of glucose suppress glucagon secretion by $\alpha$-cells, ${ }^{30-32}$ which is consistent with the suppressed glucagon secretion by iAlpha cells and islets in response to $15 \mathrm{~mm}$ glucose versus $0.4 \mathrm{~mm}$ glucose observed in the present study. Therefore, there is a dynamic equilibrium between the expression of glucagon and insulin. If glucagon levels continue to rise, it usually causes insulin resistance and glucose tolerance. In the present study, transplantation of iAlpha cells in mice resulted in higher levels of serum glucose at 4 weeks as compared to mice receiving TTFs. In addition, plasma levels of insulin and glucagon were higher in the iAlpha recipients as compared to those in the TTF recipients at 8 weeks. Thus, iAlpha cells affect the function of the islet, disrupt the insulin/glucagon equilibrium, and impact glucose homeostasis, which eventually induce insulin resistance. One interesting finding of the present study was that the graft disturbed the insulin/glucagon equilibrium and affected blood glucose homeostasis. Glucagon and insulin may constitute a feedback system that stabilizes and/or maintains blood glucose level. The higher glucagon in recipients of iAlpha cells may have enhanced plasma insulin levels, which 
may be caused by increased $\beta$-cell proliferation or enhanced insulin secretion, both of which were observed following iAlpha transplantation. Further studies are required to examine whether glucagon signaling is misregulated in vivo following transplantation of iAlpha cells.

Studies using streptozotocin (STZ) to stimulate pancreatic remodeling in rats found that it can enhance the expression of Pax $4 .{ }^{33}$ After 20 days of STZ treatment, Pax4 expression still could be detected in $\alpha$-cells, suggesting that its expression is an essential condition for transformation of $\alpha$-cells into $\beta$-cells, but it not necessarily causing $\alpha$-cell differentiation into $\beta$-cells. ${ }^{33}$ Furthermore, during embryogenesis, glucagon expression can be detected at an early stage of endocrine cell development. ${ }^{34}$ In addition, ectopic expression of Pax4-induced precursor cells to develop into $\alpha$-cells followed by $\beta$-cells. ${ }^{12}$ Lineage-tracing studies have shown that $\alpha$-cells can serve as progenitors of $\beta$-cells, resulting in the hypothesis that injured $\beta$-cells might activate $\alpha$-cells in adult islets to promote $\beta$-cell regeneration. ${ }^{35,36}$ In light of these findings, $\beta$-cells may be generated from iAlpha cells by direct conversion. This is in agreement with Klein et $a .^{37}$ in which adult human nonendocrine pancreatic tissue was converted to insulin-producing cells upon stimulation with bone morphogenic protein-7 (BMP-7). It is also in agreement with Rezania et al. ${ }^{18}$ that reported a protocol to differentiate human embryonic stem cells into $\alpha$-cells. Future studies will assess the impact of HNF $\alpha$ expression given its role in converting the pancreatic $\alpha$-cell line, $\alpha$ TC1-9 cells, into $\beta$-like cells. ${ }^{38}$

The role of Pdx1 in islet cell reprogramming is less clear. It has been shown that Pdxl expression can suppress $\delta$-subtype specification, which is likely part of the mechanism to ensure formation of distinct $\alpha$ - and $\beta$-subtypes upon coexpression of multiple reprogramming factors. ${ }^{13}$ In STZ-treated nude mice, Pdx1-positive HepG2 cells could not secret insulin, demonstrating that Pdx1 is not essential for induction of $\beta$-cells. ${ }^{39}$ However, Gao et al. ${ }^{40}$ reported that suppression of Pdx1 in $\beta$-cells resulted in cellular reprogramming that favored the $\alpha$-cell phenotype. In contrast, $\beta$-cell-specific inactivation of the $P d x 1$ gene significantly reduced glucagon mRNA levels in the islet, ${ }^{41}$ which is consistent with our observation in Figure $1 \mathrm{~b}$ showing that overexpression of Pdx1 can promote expression of glucagon.

Proliferation inhibition represents a major challenge for comprehensive application of differentiated cells. ${ }^{42}$ Because p19Arf inhibits the differentiation of cells with differentiation potential $^{43}$ and the Ink4/Arf locus is a barrier for iPS cell reprogramming, ${ }^{43}$ we have used cells from p19Arf knockout mice to analyze differentiation for the present study as in our previous studies. ${ }^{17,28}$ Further studies are required to determine if this differentiation protocol could also work for other fibroblast sources.

Other methods, including treatment with angptl4, have sought to induce $\alpha$-cell hyperplasia for the treatment of diabetes. A shared characteristic observed for both iAlpha cell transplantation and $\alpha$-cell hyperplasia is the elevated level of serum glucagon. ${ }^{44}$ However, patients treated with agents to induce $\alpha$-cell hyperplasia experience necrolytic migratory erythema and deep vein thrombosis. ${ }^{45}$ The alteration of body weight is a more complicated situation. Although the iAlpha cells induced weight loss at an early phase following transplantation, their effect on weight was not prominent at a later phase. In contrast, the loss of weight following induction of $\alpha$-cell hyperplasia is obvious. ${ }^{45} \mathrm{We}$ used p19 ${ }^{\text {Arf- }-/-}$ fibroblasts for induction of the iAlpha cells, and the biggest advantage of using the iAlpha cell is the absence of tumorigenesis potential. Thus, our method provides a reference for future clinical applications.

In addition to the small sample size of the in vivo studies, the present study is limited in that the generated $\alpha$-like cells were compared to the whole islet as a control and not $\alpha$-cells because their isolation is extremely difficult as they account for only $20 \%$ of cells in the whole islet. ${ }^{46}$ In addition, demonstration of glucagon granule formation by EM imaging was not conducted to confirm that iAlpha cells express and process glucagon; therefore, further analyses are required. Finally, the present study evaluated TTFs derived from p19Arf-1- mice; therefore, further studies are necessary to demonstrate that this approach is relevant to human cells.

In conclusion, we present a novel new strategy to generate functional $\alpha$-like cells, iAlpha cells, which demonstrate $\alpha$-cell functions in vitro and are able to disturb the blood glucose level in vivo. Thus, these cells may provide a new platform for molecule screening of $\beta$-cell conversion. Moreover, mice transplanted with iAlpha cells may serve as a disease model of insulin resistance to identify drugs for the treatment of diabetes.

\section{CONFLICT OF INTEREST}

The authors declare no conflict of interest.

\section{ACKNOWLEDGEMENTS}

The laboratory of LH is funded by the National Key Basic Research and Development Program of China (2013CB967103), the Strategic Priority Research Program of the Chinese Academy of Sciences (XDA01020308), the Hundred Talents Program (31225016), the National Natural Science Foundation of China $(81100586,81672721$, 81301722 , 91019014 and 81672721), the Natural Science Foundation of Shanghai Municipality, PR China (13ZR1410300), the National High Technology Research and Development Program of China (2013AA032202).

Author contributions: YS and LH conceived the project and designed the experiments. TL, LS and BJ carried out most of the experiments. TL, JC, XC and LS carried out most of the in vivo experiments; BJ and $\mathrm{XC}$ carried out most of the in vitro experiments; and TL and LS wrote the manuscript. ZZ and QW assisted with the statistical analysis. All authors were involved in editing the manuscript.

1 Shapiro AM, Lakey JR, Ryan EA, Korbutt GS, Toth E, Warnock GL et al. Islet transplantation in seven patients with type 1 diabetes mellitus using a glucocorticoid-free immunosuppressive regimen. N Engl J Med 2000; 343: 230-238.

2 Turgeon NA, Avila JG, Cano JA, Hutchinson JJ, Badell IR, Page AJ et al. Experience with a novel efalizumab-based immunosuppressive regimen to facilitate single donor islet cell transplantation. Am J Transplant 2010; 10: 2082-2091. 
3 Ashcroft FM, Rorsman P. Diabetes mellitus and the $\beta$ cell: the last ten years. Cell 2012; 148: 1160-1171.

4 Ryan EA, Paty BW, Senior PA, Bigam D, Alfadhli E, Kneteman NM et al. Five-year follow-up after clinical islet transplantation. Diabetes 2005; 54: 2060-2069.

5 Wang X, Metzger DL, Meloche M, Hao J, Ao Z, Warnock GL. Generation of transplantable Beta cells for patient-specific cell therapy. Int J Endocrinol 2012; 2012: 414812.

6 Gerich JE, Charles MA, Grodsky GM. Characterization of the effects of arginine and glucose on glucagon and insulin release from the perfused rat pancreas. J Clin Invest 1974; 54: 833-841.

7 Mitrakou A, Ryan C, Veneman T, Mokan M, Jenssen T, Kiss I et al. Hierarchy of glycemic thresholds for counterregulatory hormone secretion, symptoms, and cerebral dysfunction. Am J Physiol 1991; 260: E67-E74.

8 Chang AM, Jakobsen G, Sturis J, Smith MJ, Bloem CJ, An B et al. The GLP-1 derivative NN2211 restores beta-cell sensitivity to glucose in type 2 diabetic patients after a single dose. Diabetes 2003; 52: 1786-1791.

9 Unger RH, Cherrington AD. Glucagonocentric restructuring of diabetes: a pathophysiologic and therapeutic makeover. J Clin Invest 2012; 122: 4-12.

10 Thorel F, Népote V, Avril I, Kohno K, Desgraz R, Chera S et al. Conversion of adult pancreatic alpha-cells to beta-cells after extreme beta-cell loss. Nature 2010; 464: 1149-1154.

11 Liu Z, Habener JF. Alpha cells beget beta cells. Cell 2009; 138: 424-426.

12 Collombat P, Xu X, Ravassard P, Sosa-Pineda B, Dussaud S, Billestrup N et al. The ectopic expression of Pax4 in the mouse pancreas converts progenitor cells into alpha and subsequently beta cells. Cell 2009; 138 : 449-462.

13 Li W, Nakanishi M, Zumsteg A, Shear M, Wright C, Melton DA et al. In vivo reprogramming of pancreatic acinar cells to three islet endocrine subtypes. Elife 2014; 3: e01846.

14 Chen S, Borowiak M, Fox JL, Maehr R, Osafune K, Davidow L et al. A small molecule that directs differentiation of human ESCs into the pancreatic lineage. Nat Chem Biol 2009; 5: 258-265.

15 D'Amour KA, Bang AG, Eliazer S, Kelly OG, Agulnick AD, Smart NG et al. Production of pancreatic hormone-expressing endocrine cells from human embryonic stem cells. Nat Biotechnol 2006; 24: 1392-1401.

16 Kroon E, Martinson LA, Kadoya K, Bang AG, Kelly OG, Eliazer S et al. Pancreatic endoderm derived from human embryonic stem cells generates glucose-responsive insulin-secreting cells in vivo. Nat Biotechnol 2008; 26: 443-452.

17 Huang $\mathrm{P}, \mathrm{He} Z$, Ji S, Sun H, Xiang D, Liu C et al. Induction of functional hepatocyte-like cells from mouse fibroblasts by defined factors. Nature 2011; 475: 386-389.

18 Rezania A, Riedel MJ, Wideman RD, Karanu F, Ao Z, Warnock GL et al. Production of functional glucagon-secreting $\alpha$-cells from human embryonic stem cells. Diabetes 2011; 60: 239-247.

19 Xie R, Everett LJ, Lim HW, Patel NA, Schug J, Kroon E et al. Dynamic chromatin remodeling mediated by polycomb proteins orchestrates pancreatic differentiation of human embryonic stem cells. Cell Stem Cell 2013; 12: 224-237.

20 Soda Y, Marumoto T, Friedmann-Morvinski D, Soda M, Liu F, Michiue H et al. Transdifferentiation of glioblastoma cells into vascular endothelial cells. Proc Natl Acad Sci USA 2011; 108: 4274-4280.

21 leda M, Fu JD, Delgado-Olguin P, Vedantham V, Hayashi Y, Bruneau BG et al. Direct reprogramming of fibroblasts into functional cardiomyocytes by defined factors. Cell 2010; 142: 375-386.

22 Vierbuchen T, Ostermeier A, Pang ZP, Kokubu Y, Südhof TC, Wernig M. Direct conversion of fibroblasts to functional neurons by defined factors. Nature 2010; 463: 1035-1041.

23 Banga A, Akinci E, Greder LV, Dutton JR, Slack JM. In vivo reprogramming of Sox9 ${ }^{+}$cells in the liver to insulin-secreting ducts. Proc Natl Acad Sci USA 2012; 109: 15336-15341.

24 Zhou Q, Brown J, Kanarek A, Rajagopal J, Melton DA. In vivo reprogramming of adult pancreatic exocrine cells to beta-cells. Nature 2008; 455 : 627-632.

25 Pagliuca FW, Melton DA. How to make a functional $\beta$-cell. Development 2013; 140: 2472-2483.
26 Chung WS, Shin $\mathrm{CH}$, Stainier DY. Bmp2 signaling regulates the hepatic versus pancreatic fate decision. Dev Cell 2008; 15: 738-748.

27 Sapir T, Shternhall K, Meivar-Levy I, Blumenfeld T, Cohen H, Skutelsky E et al. Cell-replacement therapy for diabetes: Generating functional insulinproducing tissue from adult human liver cells. Proc Natl Acad Sci USA 2005; 102: 7964-7969.

28 Huang P, Zhang L, Gao Y, He Z, Yao D, Wu Z et al. Direct reprogramming of human fibroblasts to functional and expandable hepatocytes. Cell Stem Cell 2014; 14: 370-384.

29 Andersson A. Isolated mouse pancreatic islets in culture: effects of serum and different culture media on the insulin production of the islets. Diabetologia 1978; 14: 397-404.

30 Gaisano HY, Leung YM. Pancreatic islet alpha cell commands itself: secrete more glucagon! Cell Metab 2008; 7: 474-475.

31 Gromada J, Franklin I, Wollheim CB. Alpha-cells of the endocrine pancreas: 35 years of research but the enigma remains. Endocr Rev 2007; 28: 84-116.

32 Ravier MA, Rutter GA. Glucose or insulin, but not zinc ions, inhibit glucagon secretion from mouse pancreatic alpha-cells. Diabetes 2005; 54 1789-1797.

33 Liang XD, Guo YY, Sun M, Ding Y, Wang N, Yuan L et al. Streptozotocininduced expression of Ngn3 and Pax4 in neonatal rat pancreatic $\alpha$-cells. World J Gastroenterol 2011; 17: 2812-2820.

34 Herrera PL. $\alpha$-cell role in $\beta$-cell generation and regeneration. Development 2000; 127: 2322-2317.

35 Habener JF, Stanojevic V. $\alpha$-cell role in $\beta$-cell generation and regeneration. Islets 2012; 4: 188-198.

36 Sangan CB, Tosh D. A new paradigm in cell therapy for diabetes: turning pancreatic $\alpha$-cells into $\beta$-cells. Bioessays 2010; 32: 881-884.

37 Klein D, Álvarez-Cubela S, Lanzoni G, Vargas N, Prabakar KR, Boulina M et al. BMP-7 induces adult human pancreatic exocrine-to-endocrine conversion. Diabetes 2015; 64: 4123-4134.

38 Sangan $\mathrm{CB}$, Jover $\mathrm{R}$, Heimberg $\mathrm{H}$, Tosh D. In vitro reprogramming of pancreatic alpha cells towards a beta cell phenotype following ectopic HNF4 $\alpha$ expression. Mol Cell Endocrinol 2015; 399: 50-59.

39 Lu S, Wang WP, Wang XF, Zheng ZM, Chen P, Ma KT et al. Heterogeneity in predisposition of hepatic cells to be induced into pancreatic endocrine cells by PDX-1. World J Gastroenterol 2005; 11: 2277-2282.

40 Gao T, McKenna B, Li C, Reichert M, Nguyen J, Singh T et al. Pdx1 maintains $\beta$ cell identity and function by repressing an $\alpha$ cell program. Cell Metab 2014; 19: 259-271.

41 Li Y, Cao X, Li LX, Brubaker PL, Edlund H, Drucker DJ. beta-Cell Pdx1 expression is essential for the glucoregulatory, proliferative, and cytoprotective actions of glucagon-like peptide-1. Diabetes 2005; 54: 482-491.

42 Graf T, Enver T. Forcing cells to change lineages. Nature 2009; 462 : 587-594.

43 Li H, Collado M, Villasante A, Strati K, Ortega S, Cañamero M et al. The Ink4/Arf locus is a barrier for iPS cell reprogramming. Nature 2009; 460: 1136-1139.

44 Ouyang D, Dhall D, Yu R. Pathologic pancreatic endocrine cell hyperplasia. World J Gastroenterol 2011; 17: 137-143.

45 Chen HW, Chen HW, Su DH, Shun CT, Liu KL. Rare presentation of endocrine pancreatic tumor: a case of diffuse glucagonoma without metastasis and necrolytic migratory erythema. J Formos Med Assoc 2005; 104: 363-366.

46 Kerr JB. Atlas of functional histology. Mosby Inc.: London, UK, 1999.

$($ (1) $\Theta \Theta$ This work is licensed under a Creative Commons Attribution-NonCommercial-NoDerivs 4.0 International License. The images or other third party material in this article are included in the article's Creative Commons license, unless indicated otherwise in the credit line; if the material is not included under the Creative Commons license, users will need to obtain permission from the license holder to reproduce the material. To view a copy of this license, visit http://creativecommons.org/licenses/by-nc-nd/4.0/

Supplementary Information accompanies the paper on Experimental \& Molecular Medicine website (http://www.nature.com/emm) 